\title{
ANALYSIS AND DESIGN OF HIGH RISE BUILDING FRAME USING STAAD PRO
}

\author{
Tejashree Kulkarni ${ }^{1}$, Sachin Kulkarni ${ }^{2}$, Anjum Algur ${ }^{3}$, M. H. Kolhar ${ }^{4}$ \\ ${ }^{1,2}$ Assistant Professor, Department of Civil Engineering, SECAB Institute of Engineering \& Technology, Vijayapur- \\ 586101,VTU Belgaum, Karnataka, India \\ ${ }^{3,4}$ Associate Professor, Department of Civil Engineering, SECAB Institute of Engineering \& Technology, Vijayapur- \\ 586101,VTU Belgaum, Karnataka, India
}

\begin{abstract}
The Aim of present study "Analysis and design of high rise building by staad pro 2008" is to define proper technique for creating Geometry, cross sections for column and beam etc, developing specification and supports conditions, types of Loads and load combinations. In this study a 30- storey high rise structure is analyzed for seismic and wind load combination using staad pro 2008 and comparison is drawn.
\end{abstract}

Keywords: Analysis, Geometry, Structure, Wind load

\section{INTRODUCTION}

With the immense increase in population, demand of land keeps on mounting which in turn leads the responsibility of civil engineer to greater extent. Earlier Horizontal system of construction was in use but now a day's vertical system of construction is preferred more due to a lesser amount of ground existing. In multistoried buildings one should apprehension about all the forces acting on a structure, its self weight as well as the SBC .Good quality of beam column reinforcement should be used to counter react the external forces satisfactorily acting on a structure. The soil beneath the structure should be hard enough to distribute the load uniformly to the foundation. Deep foundation is preferred for loose soil. As number of floors keeps on increasing, manual calculations process becomes tedious, consumes more time and there are chances of human errors as well.

\subsection{Advantages of STAAD pro}

1. Extremely Flexible Modeling Environment.

2. Broad Spectra of Design Codes.

3. International Best Seller.

4. Interoperability and Open Architecture.

5. Covering All Aspects of Structural Engineering.

6. Quality Assurance.

7. Extremely Scalable.

8. Easy Reports and Documentation.

\subsection{Loads and Load Combinations}

Loads considered:

Dead load: the load due to its self weight
Live load: for residential building live load is taken as $\mathrm{KN} / \mathrm{m}^{2}$

Wind load: the load due to wind intensities.

Seismic load: the load due to acceleration response of the ground to the super structure

\section{CALCULATION OF LOADS}

\section{According to IS code:}

FOR DEAD LOAD CALCULATIONS,

Unit weight of brick masonry $=19.2 \mathrm{kN} / \mathrm{m}^{3}$.

Unit weight of RCC $=25 \mathrm{kN} / \mathrm{m}^{3}$

FLOOR FINISHES $=2 \mathrm{kN} / \mathrm{m}^{2}$ on each floor and $\left(-1.5 \mathrm{kN} / \mathrm{m}^{2}\right)$ on roof. (negative sign indicates its acting on downward direction.)

3. Wind load calculation: AS PER IS CODE 875 PART 3

4. Seismic load calculation: AS PER IS-CODE 1893(part 1)

\subsection{Load Combination}

Load combination for Static analysis:

1.5(DL + IL)

-1.2(DL $+\mathrm{IL} \pm \mathrm{EL})$

-1.5(DL $\pm \mathrm{EL})$

- 0.9 DL $\pm 1.5 \mathrm{EL}$

Load combination for For dynamic analysis:

- DL +LL

- DL+WL

$\cdot \mathrm{DL}+0.8 \mathrm{LL}+0.8 \mathrm{WL}$ 


\section{DETAILS OF THE STRUCTURE}

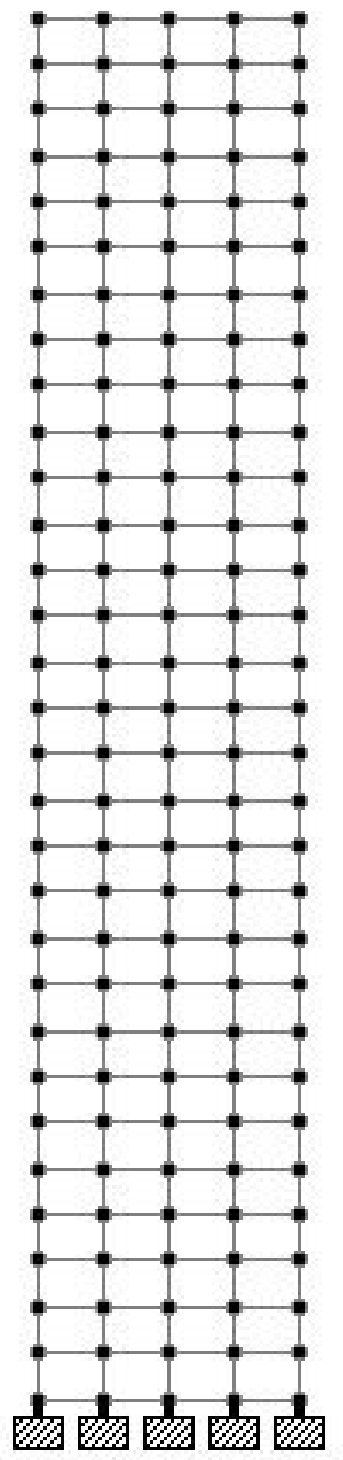

Fig-1. Elevation of structure

\subsection{Case 1. Structure Analyzed For Seismic Load}

\section{+Live Load+ Dead Load Combination.}

- Multi-storey plane frame with fixed joint is considered for the present study

- Seismic zone II is considered

- Number of stories $30,(\mathrm{G}+29)$

- Floor height considered is $3.00 \mathrm{~m}$

- 4 No of bays with $5.00 \mathrm{~m}$ bay length is considered.

- Grade of concrete considered is $\mathrm{M}_{35}$ and grade of steel considered is $\mathrm{Fe} 415$

- Size of column- $800 \mathrm{~mm} \times 800 \mathrm{~mm}$

- Size of Beam- $300 \mathrm{~mm}$ x $450 \mathrm{~mm}$

- Depth of Slab- $125 \mathrm{~mm}$ thick

- Medium soil is considered

- Response spectra analysis is carried out As per IS 1893.

\subsection{Analysis and Results}

Table 1- Shear Bending of beams and columns

\begin{tabular}{|c|c|c|c|}
\hline Particulars & $\begin{array}{c}\text { Distance } \\
(\mathrm{m})\end{array}$ & $\begin{array}{c}\mathrm{F}_{\mathrm{Y}} \\
(\mathrm{KN})\end{array}$ & $\begin{array}{c}\mathrm{M}_{\mathrm{Z}} \\
(\text { kip-in) }\end{array}$ \\
\hline BEAM 1632 & 0.00 & -8.440 & -189.057 \\
\hline BEAM 1042 & 0.00 & -40.806 & -903.712 \\
\hline BEAM 79 & 0.00 & -22.805 & -504.629 \\
\hline COLUMN 1948 & 0.00 & 13.739 & 57.642 \\
\hline COLUMN 130 & 0.00 & 37.535 & 1319.674 \\
\hline COLUMN 715 & 0.00 & 29.041 & 437.253 \\
\hline
\end{tabular}
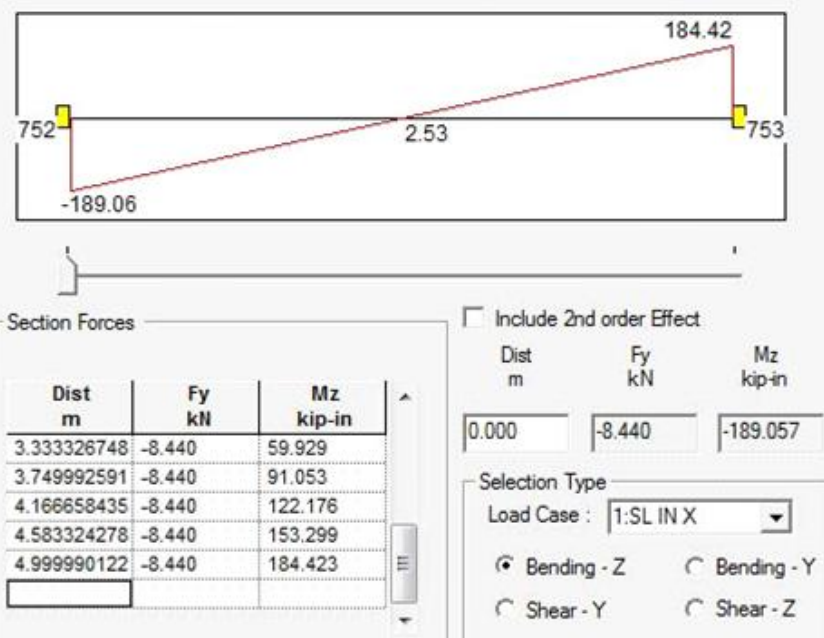

Fig 2- Shear bending of BEAM 1632

Table 2- Deflection in Beams and Columns

\begin{tabular}{|l|c|c|c|}
\hline Particulars & $\begin{array}{c}\text { DISTANCE } \\
(\mathrm{m})\end{array}$ & $\begin{array}{c}\text { DISPLACEMENT } \\
\text { (in) }\end{array}$ & $\begin{array}{c}\text { Global } \\
\text { Deflection }\end{array}$ \\
\hline BEAM 1632 & 0.00 & 6.890 & X direction \\
\hline BEAM 1042 & 0.00 & 4.256 & X direction \\
\hline BEAM 79 & 0.00 & 0.081 & X direction \\
\hline COLUMN 1948 & 0.00 & 6.809 & X direction \\
\hline COLUMN 130 & 0.00 & 0.083 & X direction \\
\hline COLUMN 715 & 0.00 & 2.527 & X direction \\
\hline
\end{tabular}
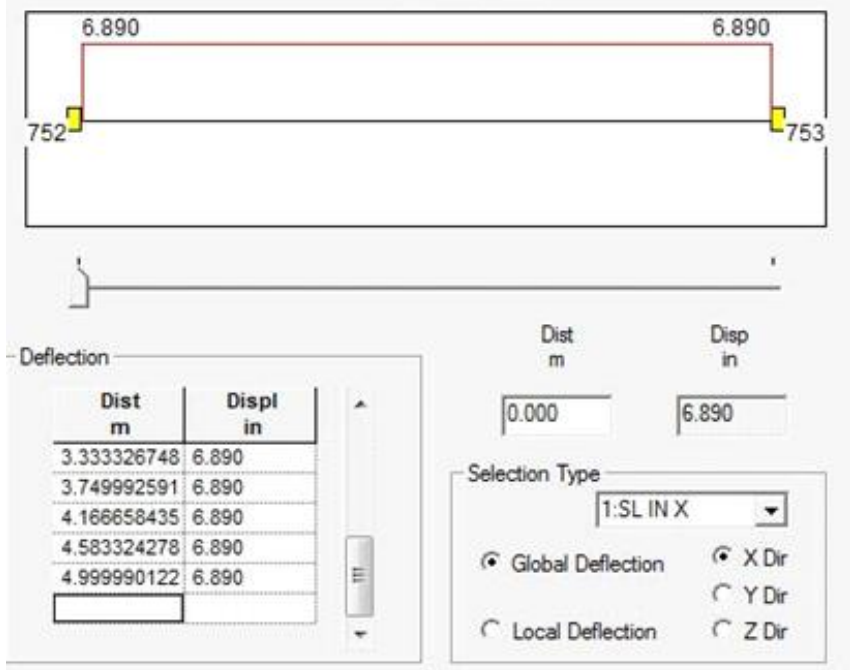

Fig 3- Deflection in BEAM 1632 


\subsection{CASE 2. STRUCTURE ANALYZED FOR}

\section{WIND LOAD + LIVE LOAD + DEAD LOAD COMBINATION.}

- Same building is considered for the study and wind analysis is carried out as per IS 875.

- Basic wind speed As per IS 875 (PART 3), $50 \mathrm{~m} / \mathrm{s}$ for CTC

- As per IS 875 (PART 3), Wind intensity and height considered is $1.5 \mathrm{kN} / \mathrm{m}^{2}$ at a height $90 \mathrm{~m}$ in CTC.

Table 3- Shear Bending of Beams and Columns for case 2

\begin{tabular}{|l|c|c|c|}
\hline \multicolumn{1}{|c|}{ Particulars } & $\begin{array}{c}\text { Distance } \\
(\mathbf{m})\end{array}$ & $\begin{array}{c}\mathbf{F}_{\mathbf{Y}} \\
(\mathbf{K N})\end{array}$ & $\begin{array}{c}\mathbf{M}_{\mathbf{Z}} \\
(\text { kip-in) }\end{array}$ \\
\hline BEAM 1632 & 0.00 & -15.467 & -353.557 \\
\hline BEAM 1042 & 0.00 & -113.008 & -2505.793 \\
\hline BEAM 79 & 0.00 & -128.012 & -2833.974 \\
\hline COLUMN 1948 & 0.00 & 29.212 & 242.395 \\
\hline COLUMN 130 & 0.00 & 164.378 & 4233.017 \\
\hline COLUMN 715 & 0.00 & 95.204 & 1237.146 \\
\hline
\end{tabular}

Table 4- Deflection in Beams and Columns

\begin{tabular}{|l|c|c|c|}
\hline Particulars & $\begin{array}{c}\text { DISTANCE } \\
(\mathrm{m})\end{array}$ & $\begin{array}{c}\text { DISPLACEMENT } \\
(\mathrm{in})\end{array}$ & $\begin{array}{c}\text { Global } \\
\text { Deflection }\end{array}$ \\
\hline BEAM 1632 & 0.00 & 13.538 & X direction \\
\hline BEAM 1042 & 0.00 & 9.399 & X direction \\
\hline BEAM 79 & 0.00 & 0.277 & X direction \\
\hline COLUMN 1948 & 0.00 & 13.398 & X direction \\
\hline COLUMN 130 & 0.00 & 0.273 & X direction \\
\hline COLUMN 715 & 0.00 & 6.155 & X direction \\
\hline
\end{tabular}

Table 5- Comparison of Seismic and wind load combinations

\begin{tabular}{|c|c|c|}
\hline Particulars & EQ+DL+LL & WL+DL+LL \\
\hline SHEAR BENDING & -189.057 kip-in & -353.557 kip-in \\
\hline DEFLECTION & 6.89 in & 13.538 in \\
\hline REINFORCEMENT & $7 \# 12$ and 6\#12 & $5 \# 12$ and $4 \# 12$ \\
\hline AREA OF STEEL & $5400 \mathbf{~ m m}^{2}$ & 5850 mm $^{2}$ \\
\hline \% OF STEEL & $\mathbf{0 . 9 8 \%}$ & $1.04 \%$ \\
\hline
\end{tabular}

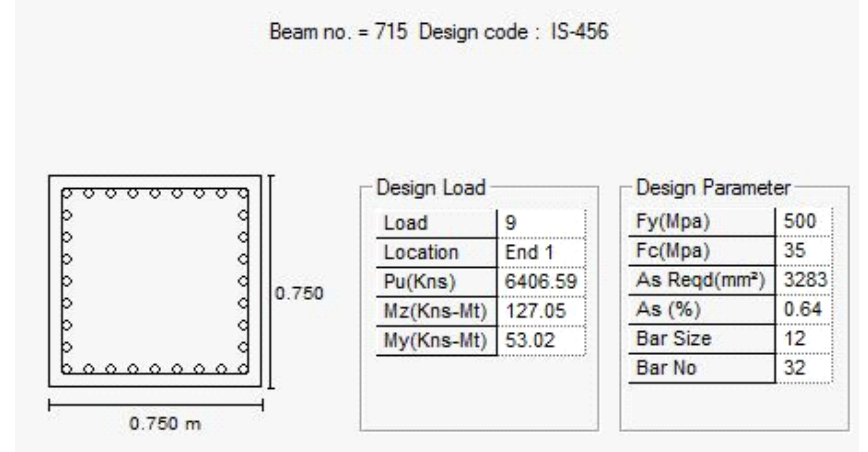

Fig 4- Concrete design of Column 715 in CASE 1

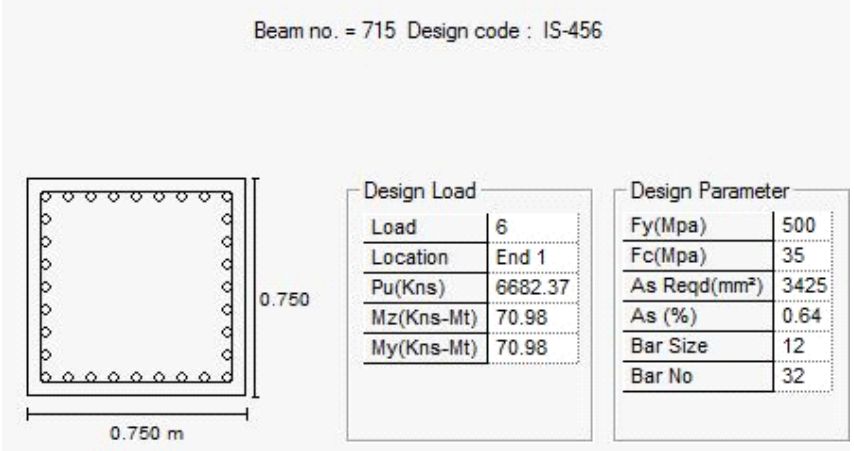

Fig 5- Concrete design of Column 715 in CASE 2

\section{CONCLUSIONS}

It can be clearly observed that when a 30- storey high rise structure with same beam and column size is analyzed and designed for static and dynamic loads:

1) The top beam of the structure requires more reinforcement in case 1 compared to case 2 . Hence it reveals that more reinforcement is required in static analysis than dynamic analysis

2) Deflection and shear bending is more in dynamic analysis compare static analysis

3) In lower beams more reinforcement is required for dynamic loads compared to static loads.

4) For columns, area of steel and percentage of steel is always greater for dynamic oad combination compared to static load combination.

\section{REFERENCES}

[1] Murty C.V.R. and Jain. S. K "A Review of IS-18931984 Provisions on seismic Design of Buildings". The Indian concrete journal, Nov.1994.

[2] Sarkar P. Agrawal, R and Menon, D."Design of beam, columns joints under Seismic loadings" A review, Journal of structural engineering SERC, Vol.33. No.6. Feb.2007.

[3] Reddell R. and Lira, J.C.D.L."Seismic analysis and design" Current practice and Future trends. Eleventh World Conference on earthquake Engineering Mexico.

[4] BIS-1893, Criteria for Earthquake resistant design of structures-Part-1, General Provisions and Buildings, Bureau of Indian Standards, New Delhi -2002.

[5] IS-456-2000 "Indian standard of code and practice for plain and reinforced concrete" Bureau of Indian Standards, New Delhi -2000.

[6] IS-875-1987."Indian standard code of practice for structural safety loadings standards" Part-1, 2 Bureau of Indian Standards, New Delhi.

[7] SP-16-1980- Design Aids for Reinforced concrete to IS-456-1978-Bureau of Indian Standards, New Delhi.

[8] Agarwal Pankaj and Shrikhande Manish "Earthquake resistant design of structure" PHI, Learning Pvt. Ltd. New Delhi-2010.

[9] Rai. Durgesh. C. Hemant. B. Kaushik, Jain.Sudhir. K."A case for use of dynamic analysis in designing for earthquake forces"- Department of Civil engineering, IIT Kanpur-India. 